\title{
Maintaining Politeness in Film Tilik: A Study of Social Distance and Power Relations on Javanese Women
}

\author{
Fenty Kusumastuti ${ }^{1, *}$, Muhammad Taufiq al Makmun², Karunia Purna Kusciati ${ }^{3}$ \\ 1,2,3, Universitas Sebelas Maret Surakarta, Indonesia \\ *Corresponding author. Email: fentykusumastuti@staff.uns.ac.id
}

\begin{abstract}
The paper aims to identify the Javanese cultural concept, especially from how the women preserve their politeness strategies in the short film, Tilik, produced by the Racavana Films in 2018. To accomplish the goals, this research applied a descriptive qualitative method that involves attention to document review. The data are gathered into the nine acts of the thirty-two-minute film to investigate an interpretive description of the Javanese women reflecting their socio-psychological behavior through the social distance and power relations. This sociolinguistic analysis benefits from decoding the gap between identity and language as part of the Javanese social and cultural phenomenon of the early millennials. The approaches applied in the study are based on the trichotomous politeness systems presented by Yabuuchi that fit in the framework of the Javanese social distance and power. Meanwhile, the theory of gender, language, and power relations contributed by Leech, Smith-Hefner, Wierzbicka, and Holmes might illustrate an outline of Javanese women's politeness within their social distance and dominance that mainly occur in collectivistic cultures like Javanese society. Thus, a broad pattern is identified from the film: Javanese women have a complex strategy to sustain their politeness when interacting with other people. However, negotiating impoliteness from only linguistic perspectives is not enough. Hence, the identification of ingratiation triggered by power difference becomes one of the most significant features in maintaining politeness strategy.
\end{abstract}

Keywords: Javanese politeness, Cultural concept, Javanese women, Power relations, Social distance

\section{INTRODUCTION}

Javanese people are prominent in their language propriety that discusses how to behave, handle a conversation, and control their physical gestures to accompany the speech act [1]. As the language speech act is not the most principle in Javanese politeness, the saving face strategies by Brown and Levinson [2] may not be the only way to maintain mannerliness, specifically in a collectivist society like Indonesia, where most of the early millennials speak bilingually. However, face or dignity damage is still a threat when responding to impoliteness as studied by Jan and How when examining the participants of the reality TV show 'The Amazing Race Asia' [3]. Hence, the points presented here in this paper are intended to identify the Javanese cultural concept illustrated by the Javanese women in film Tilik (2018) and to observe how the Javanese women in the truck claim to be modern yet preserving Javanese politeness while having a conversation and gossiping about other people on their way to visit Ibu Lurah who falls ill in the hospital.

Recognizing that a new era of the internet has ushering our life for anything and everything, Wahyu Agung Prasetyo, creates the short film Tilik to bring two central ideas into the society: internet hoaxes and woman's freedom in choosing her own life [4]. The film is about a group of women visiting Ibu Lurah, the head of the village, by riding a truck, while talking about Dian's life, the most beautiful girl in their village. Winning Piala Maya in 2018 and becoming the Official Selection for Jogja-Netpac Asian Film Festival 2018 and The World Cinema Amsterdam 2019, this film has gained around 25 million viewers in the legal channel produced by Racavana Films, cooperated with the Department 
of Culture of Yogyakarta released freely in YouTube channel. The success of this film brings much discussion that reflects the reality in Javanese society, especially among women. However, the activity of talking about others who were not present at the talks that are widely known as 'ngrasani' or 'gossiping' is considered harmful because it has the power to shape others' reputation and identity [5].

One's identity is no longer seen as an innate construct but instead adjusts to cultural and societal contexts [6]. As such, politeness might imply an individual's identity, as demonstrated by the Iranian when establishing their interlocutors' status in the structure or hierarchy of the group [7]. For them and other non-western cultures, applying Brown and Levinson's model on politeness theory needs more prominent strategies, such as giving deference, hedging, and impersonalization [2]. It is also evident that there is a relationship between language and social identity, especially on how males and females communicate in a conversation that contributes to their status in society. A recent study in Iran shows that female participants have a great tendency to uphold their power dominance and control over their peers during a conversation [8].

Undoubtedly, many studies have been conducted to see gender and power relations through culture. It seems that Tilik is not the only film that portrays the idea of gender, culture, and power because the most dreaded supernatural being in Malaysian horror films also suggests a broader challenge to female empowerment as a cultural belief [9]. However, released on YouTube channel on August 17, 2020, film Tilik has captivated many groups of people, including the academicians, to discuss and analyze the film. Some of them involve a reception response of the mothers in Bantul about the culture of visiting the sick [10], and the analysis of Ibu Tedjo's directive speech acts that show her dominance among others [11]. On the other hand, the state of the art of this study focuses on the language politeness used in the film to see how it portrays the Javanese cultural concept, especially related to gender and power relations.

\section{JAVANESE CULTURAL CONCEPT}

In Java, indirectness is much right as an attempt to achieve polite action. However, this may not always be accurate in all contexts of situations for English communities and other cultures because directness is considered more polite in order to perform solidarity and closeness with other interlocutors [12]. According to other scholars' research on the study of (im)politeness that it indicates cultural factors as a more influential aspect to the awareness of communication [13]. As one of the oldest civilizations in Indonesia that highly inspired by the refined aristocratic culture of Keraton Yogyakarta and Surakarta, Javanese culture values polite and refined language. They are renowned for the indirectness to avoid conflict. As a matter of fact, in the Javanese community, indirectness is closely related to another Javanese cultural norm that Geertz called 'dissimulation' or 'pretense' as one of the strategies to negotiate impoliteness [14].

Besides indirectness, the use of speech levels is common to indicate the attitude of the speaker to the addressee that is divided into two significant distinctions: ngoko, the most basic and familiar level used by lower social rank, and krama, used by unfamiliar or higher status persons [15]. Nevertheless, Tilik uses mostly ngoko because the given situation is among peers with the same-gender conversation. Some of the exceptions in mixed-gender conversation include chatting with Gotrek, the police officer, Fikri, and Fikri's father that only take a small part of the film. In general, women are much more likely to express politeness to men. Women's utterances indicate a marker of concern for the interlocutors' feelings that is even more obvious than men [16]. Without a doubt, there is an empirical study of gender differences in the use of language politeness, especially amongst the Javanese women. Some of the discussions have particular concerns about the analysis of formal aspects, power relations, and criticism involved in evaluating (im)politeness such as intention, identity, moral orders, and utterances or actions [17]. These previous studies shed light on how the utterances among Javanese women aim to assert their attention. 


\section{MATERIALS AND METHODS}

This research adopts a descriptive qualitative method that involves naturalistic data, meaning without any intervention or manipulation of the setting [18]. The essential materials of this paper is the film Tilik initiated by Racavana Films and the Department of Culture, Yogyakarta, directed by Wahyu Agung Prasetyo. First produced in 2018, this film is only uploaded to the YouTube channel on August 17, 2020. Tilik is a 32-minute film in the Javanese language that means 'to visit.' The exploration of a film such as Tilik connects the readers and the viewers to social, spatial, and temporal networks of exchange and meaning [19]. Moreover, no matter the approaches used to study film cultures, the relationship to film is to question how the film connects us to social and cultural phenomena. Thus, this paper sees the transcript of the language used in the film and subjective personal experience with the film and reflects the social and cultural values portrayed in the film.

The procedures done in this research include collecting the transcript of the film's utterances, observing the technical sides of the film such as the gestures of the characters, the setting, the clothes, camera, sound to help the researcher create the reasoning on the moving image. The film is divided into nine acts that fit the storyline based on the: (1) Who is Dian? (2) News from the internet; (3) Throw up = Pregnant? (4) Black campaign; (5) Slander; (6) Again, news from the internet; (7) Caught by the police officer; (8) At the hospital; and (9) Dian is ...The nine acts proposed by Rura helped to comprehend the main narrative most efficiently because each act consists of different elements that give a detailed overview on various Javanese contextual [20]. Referring to a socio-psycholinguistic perspective by Yabuuchi's trichotomous politeness system, this research expects to identify the power relations and social identity of the Javanese women throughout the film [21]. The data are further interpreted for evaluation of analysis in the discussion and summarized into a conclusion.

\section{FINDINGS AND DISCUSSION}

Based on the plot of the film, nine parts are treated to structure the Javanese contextual background. They are (1) Who is Dian? (2) News from the internet; (3) Throw up = Pregnant? (4) Black campaign; (5) Slander; (6) Again, news from the internet; (7) Caught by the police officer; (8) At the hospital; and (9) Dian is ... The following is the finding of the research presented in the table using the strategies to maintain politeness constrained by the Javanese cultural concept.

Table 1: Maintaining politeness in Film Tilik

\begin{tabular}{|c|c|c|c|c|c|c|}
\hline \multirow[t]{2}{*}{ No } & \multirow[t]{2}{*}{ Acts } & \multicolumn{2}{|c|}{ Strategies of politeness } & \multicolumn{3}{|c|}{ Javanese Cultural Concept } \\
\hline & & $\begin{array}{c}\text { Social } \\
\text { distance }\end{array}$ & $\begin{array}{c}\text { Power } \\
\text { relations }\end{array}$ & Gender & $\begin{array}{l}\text { Language } \\
\text { Speech act }\end{array}$ & Ingratiation/Indirectness \\
\hline 1. & $\begin{array}{l}\text { Who is } \\
\text { Dian? }\end{array}$ & Autonomy & $\begin{array}{l}\text { Hierarchy } \\
\text { politeness } \\
\text { (UHNP) } \\
\text { Hierarchy } \\
\text { politeness } \\
\text { (DHNP) } \\
\text { Hierarchy } \\
\text { politeness } \\
\text { (UHNP) }\end{array}$ & $\begin{array}{l}\text { Same- } \\
\text { gender: } \\
\text { woman to } \\
\text { woman }\end{array}$ & Ngoko & $\begin{array}{l}\text { Yu Sam looks for opportunities to let Bu Tedjo know } \\
\text { her virtues/values (upward). } \\
\text { Bu Tedjo persuasively presents her own qualities } \\
\text { when attempting to convince the others about her } \\
\text { abilities (downward). } \\
\text { Yu Sam and Bu Tri show their enthusiasm about Bu } \\
\text { Tedjo's discovery on Dian (upward). }\end{array}$ \\
\hline 2. & $\begin{array}{l}\text { News } \\
\text { from the } \\
\text { internet }\end{array}$ & $\begin{array}{l}\text { Autonomy } \\
\text { Fellowship }\end{array}$ & $\begin{array}{l}\text { Hierarchy } \\
\text { politeness } \\
\text { (DHNP) } \\
\text { Sincere } \\
\text { fellowship }\end{array}$ & $\begin{array}{l}\text { Same- } \\
\text { gender: } \\
\text { woman to } \\
\text { woman }\end{array}$ & $\begin{array}{l}\text { Ngoko alus } \\
\text { (Njenengan) }\end{array}$ & $\begin{array}{l}\text { Bu Tejo indirectly talks to Yu Sam when she knows } \\
\text { and wants everyone in the truck can hear her } \\
\text { (downward). } \\
\text { Yu Ning looks for opportunities to let Bu Tedjo and } \\
\text { the others know about the news hoax on the } \\
\text { internet. }\end{array}$ \\
\hline 3. & $\begin{array}{l}\text { Throw up } \\
= \\
\text { pregnant } \\
?\end{array}$ & Autonomy & $\begin{array}{l}\text { Hierarchy } \\
\text { politeness } \\
\text { (UHNP) } \\
\text { Hierarchy } \\
\text { politeness } \\
\text { (UHNP) }\end{array}$ & $\begin{array}{l}\text { Same- } \\
\text { gender: } \\
\text { woman to } \\
\text { woman }\end{array}$ & Ngoko Alus & $\begin{array}{l}\text { Yu Sam disagrees on trivial/unimportant issues such } \\
\text { as Dian's pregnancy but agrees on the previous } \\
\text { issues she expects support from Bu Tedjo (upward). } \\
\text { Bu Tri expresses the opinion similar to Bu Tedjo's } \\
\text { idea to let her know that they are alike (upward). }\end{array}$ \\
\hline
\end{tabular}




\begin{tabular}{|c|c|c|c|c|c|c|}
\hline 4. & $\begin{array}{l}\text { Black } \\
\text { campaig } \\
n\end{array}$ & $\begin{array}{l}\text { Fellowship } \\
\text { Autonomy }\end{array}$ & $\begin{array}{l}\text { Hierarchy } \\
\text { politeness } \\
\text { (DHNP) } \\
\text { Hierarchy } \\
\text { politeness } \\
\text { (DHNP) }\end{array}$ & $\begin{array}{l}\text { Mixed- } \\
\text { gender: } \\
\text { woman to } \\
\text { man } \\
\text { Same- } \\
\text { gender: } \\
\text { woman to } \\
\text { woman }\end{array}$ & Ngoko & $\begin{array}{l}\text { Bu Tedjo gives money to Gotrek to show her selfless } \\
\text { generosity (downward). } \\
\text { Bu Tedjo tries to persuasively show Dian's and Bu } \\
\text { Lurah's lack of quality to convince the village } \\
\text { (downward). }\end{array}$ \\
\hline 5. & Slander & $\begin{array}{l}\text { Fellowship } \\
\text { Fellowship } \\
\text { Fellowship }\end{array}$ & $\begin{array}{l}\text { Hierarchy } \\
\text { politeness } \\
\text { (DHNP) } \\
\text { Hierarchy } \\
\text { politeness } \\
\text { (UHNP) } \\
\text { Hierarchy } \\
\text { politeness } \\
\text { (DHNP) }\end{array}$ & $\begin{array}{l}\text { Same- } \\
\text { gender: } \\
\text { woman to } \\
\text { woman }\end{array}$ & $\begin{array}{l}\text { Ngoko alus } \\
\text { (Njenengan) }\end{array}$ & $\begin{array}{l}\text { Bu Tedjo offers to help Yu Ning look for a bus by } \\
\text { using her husband's contact (downward). } \\
\text { Bu Tri shows Bu Tedjo that she shares her } \\
\text { enthusiasm about Dian (upward). } \\
\text { Bu Tedjo looks for opportunities to let the others } \\
\text { know her virtues/values by asking if Dian has charm } \\
\text { (downward). }\end{array}$ \\
\hline 6. & $\begin{array}{l}\text { Again, } \\
\text { news } \\
\text { from the } \\
\text { internet }\end{array}$ & $\begin{array}{l}\text { Fellowship } \\
\text { Fellowship } \\
\text { Autonomy } \\
\text { Fellowship } \\
\text { Fellowship } \\
\text { Autonomy }\end{array}$ & $\begin{array}{l}\text { Hierarchy } \\
\text { politeness } \\
\text { (UHNP) } \\
\text { Hierarchy } \\
\text { politeness } \\
\text { (DHNP) } \\
\text { Insincere } \\
\text { fellowship } \\
\text { Hierarchy } \\
\text { politeness } \\
\text { (UHNP) } \\
\text { Hierarchy } \\
\text { politeness } \\
\text { (DHNP) } \\
\text { Sincere } \\
\text { autonomy }\end{array}$ & $\begin{array}{l}\text { Same- } \\
\text { gender: } \\
\text { woman to } \\
\text { woman }\end{array}$ & $\begin{array}{l}\text { Ngoko alus } \\
\text { (Njenengan) }\end{array}$ & $\begin{array}{l}\text { Yu Ning looks for opportunities to let her opponent, } \\
\text { Bu Tedjo, know her virtues/strength (upward). } \\
\text { Bu Tedjo tries to let Yu Ning know that her husband } \\
\text { has a reputation for being liked (downward). } \\
\text { Bu Tedjo indirectly changes the interlocutors from Yu } \\
\text { Ning to Yu Sam because she does not want to show } \\
\text { her disagreement with Yu Ning directly } \\
\text { (indirectness). } \\
\text { Bu Tri let Bu Tedjo know the attitudes she shares } \\
\text { with her by giving her opinion on Dian (upward). } \\
\text { Bu Tedjo tries to do things for the people in the } \\
\text { village that shows her selfless generosity by } \\
\text { spreading the news about Dian to alert the } \\
\text { housewives in the village (downward). } \\
\text { Yu Ning lets Bu Tedjo know her strength by openly } \\
\text { gives her a negative opinion toward her. }\end{array}$ \\
\hline 7. & $\begin{array}{l}\text { Caught } \\
\text { by the } \\
\text { police } \\
\text { officer }\end{array}$ & $\begin{array}{l}\text { Autonomy } \\
\text { Fellowship }\end{array}$ & $\begin{array}{l}\text { Hierarchy } \\
\text { politeness } \\
\text { (DHNP) } \\
\text { Hierarchy } \\
\text { politeness } \\
\text { (DHNP) }\end{array}$ & $\begin{array}{l}\text { Mixed- } \\
\text { gender: } \\
\text { woman to } \\
\text { man }\end{array}$ & $\begin{array}{l}\text { Bahasa } \\
\text { Indonesia, } \\
\text { Ngoko }\end{array}$ & $\begin{array}{l}\text { Bu Tedjo intimidates the police officer by using her } \\
\text { relatives' personal contact (downward). } \\
\text { Bu Tedjo persuasively presents her ability to } \\
\text { threaten the police officer by asking others to join her } \\
\text { (downward). }\end{array}$ \\
\hline 8. & $\begin{array}{l}\text { At the } \\
\text { hospital }\end{array}$ & $\begin{array}{l}\text { Autonomy } \\
\text { Autonomy } \\
\text { Fellowship } \\
\text { Fellowship } \\
\text { Fellowship } \\
\text { Fellowship }\end{array}$ & $\begin{array}{l}\text { Hierarchy } \\
\text { politeness } \\
\text { (UHNP) } \\
\text { Hierarchy } \\
\text { politeness } \\
\text { (DHNP) } \\
\text { Hierarchy } \\
\text { politeness } \\
\text { (UHNP) } \\
\text { Hierarchy } \\
\text { politeness } \\
\text { (UHNP) } \\
\text { Hierarchy } \\
\text { politeness } \\
\text { (DHNP) } \\
\text { Hierarchy } \\
\text { politeness } \\
\text { (DHNP) }\end{array}$ & $\begin{array}{l}\text { Mixed- } \\
\text { gender: } \\
\text { man to } \\
\text { woman } \\
\text { Same- } \\
\text { gender: } \\
\text { Woman to } \\
\text { woman }\end{array}$ & Krama & $\begin{array}{l}\text { Fikri expresses gratitude to the visitors, even though } \\
\text { it is not a good time to visit his mother (upward). } \\
\text { Bu Tedjo tries to make sure that she is aware of } \\
\text { Dian and Fikri's relationship (downward). } \\
\text { Yu Ning gives the money collected from the visitors } \\
\text { to Fikri as an expression of sympathy to Bu Lurah } \\
\text { (upward). } \\
\text { Yu Ning tries to convince Bu Tedjo that her idea of } \\
\text { visiting Bu Lurah is selfless generosity (upward). } \\
\text { Bu Tedjo shows Yu Ning that what Yu Ning did is } \\
\text { similar to what Bu Tedjo did and that they both are } \\
\text { alike (downward). } \\
\text { Bu Tedjo looks for opportunities to let the others } \\
\text { know her virtues/values by giving suggestions to go } \\
\text { to the market instead of going straight home } \\
\text { (downward). }\end{array}$ \\
\hline 9. & Dian is & $\begin{array}{l}\text { Fellowship } \\
\text { Fellowship }\end{array}$ & $\begin{array}{l}\text { Sincere } \\
\text { fellowship } \\
\text { Sincere } \\
\text { fellowship }\end{array}$ & $\begin{array}{l}\text { Mixed- } \\
\text { gender: } \\
\text { woman to } \\
\text { man }\end{array}$ & Ngoko & $\begin{array}{l}\text { Dian asks Fikri's father or her future husband if there } \\
\text { is a hope in the future that their life together will be } \\
\text { better. } \\
\text { Fikri's father tries to convince Dian to believe in him } \\
\text { that one day everything will be better. }\end{array}$ \\
\hline
\end{tabular}


There are two significant events that happen in the first act: (1) Yu Sam opens a conversation with $\mathrm{Bu}$ Tedjo by asking about Dian, and (2) Bu Tedjo presents herself to know more about Dian. In the first event, Yu Sam practically looks for opportunities to let $\mathrm{Bu}$ Tedjo know her values while Bu Tedjo seems does not care with the only short response of 'Hah?' and 'Really?' to show her being more superior than Yu Sam. Even Bu Tri wants to know more and asks Yu Sam how she knew the news, and she pointed to Yu Ning. The power relations belong to hierarchy politeness with Upward Hierarchical Negative Politeness (UHNP) because $\mathrm{Bu}$ Tedjo does not consider herself equal with the others, even when Yu Sam tries to be likable by her fellows (Bu Tedjo, Bu Tri, and the others), but the purpose of Yu Sam asking about Dian is more of her wants to be desirable by $\mathrm{Bu}$ Tedjo. Therefore, she performs fellowship in the social distance because she maintains her self-image to be appreciated and approved by others.

Meanwhile, the language used is Ngoko because the conversation is between women. At the end of the first act, Yu Sam and Bu Tri show their enthusiasm for Bu Tedjo's discovery on Dian to illustrate the fellowship of their social distance. However, somehow Ibu Tedjo sees herself as more competent than the others, wishing for more approval. Her revealing something that the others may not know before is a photo of Dian getting close to some man found on the internet.

Act Two is the first conversation about the news that Ibu Tedjo obtained about Dian from the internet. She does not show the news to be accepted by the others, but more of autonomy, an essential claim to her personal domains, as a person who knows more than the others. Hardly surprising that $\mathrm{Yu}$ Ning is upset when she hears about the news and protests to $\mathrm{Bu}$ Tedjo immediately. Therefore, Bu Tedjo applies the Downward Hierarchical Negative Politeness strategy (DHNP) by indirectly talking to Yu Sam even though she knows and deliberately wants the others to listen to her. On the other hand, Yu Ning feels the urgency to let $\mathrm{Bu}$ Tedjo and the others know about the news hoax on the internet, learning from the experience of a herbal medicine company deceiving the whole villagers. She is also using ngoko alus when talking to Bu Tedjo by addressing 'Njenengan,' and Bu Tedjo replied by addressing the name 'Yu Ning' and indirectly talk to Yu Sam or the others as a diversion to a direct speech. It shows that Yu Ning is friendlier to fellowship and sincere to her community without having any hidden agenda of being admired by the others.

She recognizes the previous conversation between $\mathrm{Yu}$ Sam and $\mathrm{Bu}$ Tedjo and how she always looks for her approval and supports her statements that it seems strange to know that she disagrees with her testimony about Dian's pregnancy. Her awareness that her earlier approach to Bu Tedjo as an equivalent fellowship ended by $\mathrm{Bu}$ Tedjo shows her awareness might trigger her autonomy. Nonetheless, this situation changes their social distance from fellowship to autonomy as Yu Sam tries to be as competent as $\mathrm{Bu}$ Tedjo. However, it is still considered hierarchy politeness that belongs to UHNP because Yu Sam's seek involvement can be considered a step from admiration to envy to jealousy. Thus, $\mathrm{Bu}$ Tedjo is still respected as a more powerful person in their community. Moreover, at this stage, $\mathrm{Bu}$ Tri replaces the previous Yu Sam when she supports Bu Tedjo and even expresses her opinion as a way to let others know that both are alike. Bu Tri also applies to UHNP, but because she tries to be desirable by Bu Tedjo, she fits with fellowship as her social distance strategy.

The two events in act 4 show similar power relations of hierarchy politeness with DHNP between $\mathrm{Bu}$ Tejo and the others (Gotrek, Yu Ning, and other women in the truck) that expose her higher social status as also seen from how she shows her gold bracelets, her utterances, and her gestures. However, her social distance alters from fellowship to autonomy when she moves from giving money to Gotrek to persuasively showing Dian's and Bu Lurah's negative quality in order to convince the other of her selfless generosity. She seems to be a person of ability and has the virtues of an influential and prosperous powerful person, but then becomes autonomy as she shows her negative face that her actions should not be impinged by others.

Like the previous one, this act still involves $\mathrm{Bu}$ Tedjo's DHNP by showing her selfless generosity when convincing $\mathrm{Yu}$ Ning about her 
husband's positive reputation and spreading the negative news about Dian as an alert to the housewives in the village. Moreover, her using of 'Njenengan' to address Yu Ning is different from the previous address forms she uses that perhaps because of the way $\mathrm{Yu}$ Ning pointed her imperfections directly in front of the others. In order to save her face, she is using fellowship as her social distance strategy to be accepted in the group. However, until Yu Ning changes the subject of the conversation back into Dian again, $\mathrm{Bu}$ Tedjo seems to get an opportunity to show her autonomy by indirectly showing her disagreement, through changing the interlocutor from $\mathrm{Yu}$ Ning to $\mathrm{Yu}$ Sam. However, the situation might trigger $\mathrm{Yu}$ Ning's autonomy at the end of act 6 as a mature and responsible adult who openly let the others know of her sincere autonomy that it is prominent to stay alert on news hoaxes on the internet, and how she does not like a person of slander and arrogant like $\mathrm{Bu}$ Tedjo.

In this short act, there are two events that involve a conversation between Bu Tedjo and the police officer. Both events show Bu Tedjo's position as a more powerful person than the police officer. She uses her relatives' personal contact to treat him and presents her abilities to bend the law. However, her first threat is considered autonomy to show her initiative as a reliable person but then alters to fellowship when she leads the others to attack the police officer cooperatively.

Arriving at the hospital and meeting Fikri and Dian makes the situation calm. Most of the social distance strategies amongst them belong to a fellowship, except for Yu Ning's conversation to Fikri and Bu Tedjo's statement or question to Fikri and Dian that fit autonomy because of their distant degree intimacy. At this event, Bu Tedjo only tries to make sure that they know and are aware of Dian and Fikri's relationship, whatever it is, as they are seen together accompanying $\mathrm{Bu}$ Lurah in the hospital. On the other hand, the power relations are seen as usual, that Bu Tedjo's utterances demonstrate DHNP while the others indicate UHNP, such as Yu Ning and Fikri. For Fikri and Dian, it is Javanese behaviors to always speak krama to the elders and give deference by expressing gratitude and asking for an apology to those who have arrived but could not visit his mother. However, Yu Ning's events are a little bit different. At this act, she is disappointed for not being able to visit $\mathrm{Bu}$ Lurah and therefore asks for $\mathrm{Bu}$ Tedjo's support that her idea is selfless generosity.

The last act in the film is quite shocking to the audience because it reveals the truth about what $\mathrm{Bu}$ Tedjo and friends talk about, which is Dian and her relationship with Fikri. However, this conversation between Dian and Fikri's father illustrates a deep connection involving affection, care, acceptance, and love; therefore, it goes along with fellowship as their strategy in social distance. Meanwhile, their power relations do not show any ingratiation, and the deference is sincere to the attribute they share. Nevertheless, it is a bit strange that Dian does not talk krama to her future husband, especially in Javanese tradition where most women show respect to their men by speaking a high-level speech act of krama. It might show that this couple is already modern and has no boundaries toward each other [22].

\section{CONCLUSION}

The strategies of politeness that affect the social distance between the interlocutors' interchanges between fellowship and autonomy depend on the speakers' intention when communicating the expressions that are not always linguistically obvious and psycholinguistically concealed, such as in the form of ingratiation or indirectness. Most of the time, the direction of the ingratiation demonstrates the power relations between the interlocutors, which may go upward or downward subjects to the speaker's position in a social hierarchy. Meanwhile, the gender of the interlocutors might not be visibly perceived in this film due to its lack of variability and more of the same-gender conversation. However, it is sufficient to show the variety of the language speech act used between the mixed-gender speakers, including ngoko, Indonesian, and krama. Finally, it can be concluded from the film that Javanese women have a complex strategy to maintain their politeness as seen from the power difference and social distance, primarily through the identification of the Javanese cultural concept of ingratiation and indirectness. 


\section{ACKNOWLEDGMENTS}

We thank the University Centre of Excellence, Javanology for Javanese Traditions, Universitas Sebelas Maret, Surakarta, and the International Conference on Language Politeness "Language Politeness: Millennial Generation in the New Normal Era" for support.

\section{REFERENCES}

[1] Poedjosoedarmo, S. (2017). Language propriety in Javanese. Journal of Language and Literature, 17(1), 1-9.

[2] Brown, P., \& Levinson, S. C. (1978). Universals in language usage: Politeness phenomena. In Questions and politeness: Strategies in social interaction (pp. 56-311): Cambridge University Press.

[3] Jan, J. M., \& How, C. (2015). Discursive Construction of Asian Responses towards Impoliteness. Pertanika Journal of Social Sciences \& Humanities, 23.

[4] Dwiastono, R. (2020). Kisah di balik layar, kontroversi, dan prospek layar lebar "Tilik" serta viralnya soso Bu Tejo.

[5] Nycyk, M. (2015). The Power Gossip and Rumour Have in Shaping Online Identity and Reputation: A Critical Discourse Analysis. Qualitative Report, 20(2).

[6] Sulaiman, N. F. (2014). Cultural Identity at the Liminal Spaces: A Study of Wakako Yamauchi's and The Soul Shall Dance. Pertanika Journal of Social Sciences \& Humanities, 22(4).

[7] Izadi, A. (2013). Politeness in spoken review genre: Viva voce context. Pertanika Journal of Social Science and Humanities, 21(4), 13271346.

[8] Jan, J. M., \& Mohajer, L. (2012). Interruption as Power Ploy in Women's Conversation. Pertanika Journal of Social Sciences \& Humanities, 20(4).

[9] Lee, Y. (2016). The Villainous Pontianak? Examining Gender, Culture, and Power in Malaysian Horror Films. Pertanika Journal of Social Sciences \& Humanities, 24(4).

[10] Tutiasri, R. P., Yuliani, E. R., Purnamasari, N. P., \& Putri, C. O. (2020). Analisis Resepsi Budaya Menjenguk Orang Sakit Dalam Film Pendek Tilik Pada Ibu-Ibu Di Kabupaten Bantul. voxpop, 2(1), 100-115.
[11] Christina, C. (2020). The Analysis of Bu Tejo's Language in Short Movie "Tilik". Metaphor, $3(1), 56-67$.

[12] Leech, G. (1983). Principles of Pragmatics Text. London, NY: Longman.

[13] Chang, W.-L. M. (2008). Australian and Chinese perceptions of (im) politeness in an intercultural apology.

[14] Wierzbicka, A. (2003). Cross-cultural pragmatics: Walter de Gruyter Inc.

[15] Smith-Hefner, N. J. (1988). Women and politeness: The Javanese example. Language in society, 535-554.

[16] Holmes, J. (2013). Women, men and politeness: Routledge.

[17] Norwanto, N. (2016). Gender and Politeness in Javanese Language. University of Huddersfield,

[18] Nassaji, H. (2015). Qualitative and descriptive research: Data type versus data analysis. Sage UK: London.

[19] Harbord, J. (2002). Film cultures: Sage.

[20] Rura, C. (2020). Ulasan Film Tilik dalam 9 Babak.

[21] Yabuuchi, A. (2006). Hierarchy politeness: What Brown and Levinson refused to see. Intercultural Pragmatics, 3(3), 323-351.

[22] Warto, \& B Mohamad (2016). The Relationship Between Jipang and Pajang in the Oral Tradition: Between History and Memory, Advanced Science Letters 22 (12), 4426-4430 